\title{
Efektivitas Siswa Melalui Model Pembelajaran Ekspositori Terhadap Prestasi Belajar Pada Siswa Kelas I SD Negeri 4 Barenglor
}

\author{
Sri Suwartini, M.Pd \\ PGSD Unwidha \\ srititin@unwidha.id
}

\begin{abstract}
Abstrak
Metode Ekspositori adalah metode pembelajaran yang menekankan pada proses penyampaian materi secara verbal dari seorang guru kepada sekelompok siswa dengan maksud agar siswa dapat menguasai materi pelajaran secara optimal. Subyek penelitian adalah 48 siswa kelas I semester II SD Negeri 4 Bareng Lor Tahun Akademik 2017/2018. Hasil penelitian menggambarkan bahwa metode pembelajaran yang digunakan guru hanya terpusat pada salah satu metode pembelajaran. Untuk itu diperlukan metode pembelajaran yang efektif yang dipakai oleh guru dalam proses pembelajaran sehingga akan termotivasi dengan metode pembelajaran tersebut

Berdasarkan hasil analisis data diperoleh perbedaan yang berarti antara prestasi belajar yang menggunakan model pembelajaran ekspositori dengan metode pembelajaran lain. Hal ini dapat dilihat dari uji independensi yang menunjukkan hasil signifikansi kurang dari 0,05 ( $\operatorname{sig}<0,05)$.

Kemudian dilihat dari reratanya, pembelajaran dengan mengacu pembelajaran ekspositori dapat diperoleh prestasi belajar (yaitu 46) menghasilkan rerata yang lebih tinggi dibandingkan dengan metode pembelajaran lain (yaitu 44). Jadi kesimpulannya adalah model pembelajaran ekspositori adalah pembelajaran yang efektif.
\end{abstract}

Kata Kunci: Efektivitas, Ekspositori, Prestasi Belajar

\section{PENDAHULUAN}

Pendidikan adalah kunci kebangkitan, kemajuan, kejayaan suatu bangsa. Bangsa yang peduli dengan dunia pendidikanya, maka negara itu akan cepat maju dan sebaliknya

Guru yang memiliki tingkat abstraksi yang tinggi adalah guru yang mampu mengelola tugas, menemukan berbagai permasalahan dalam tugas, dan mampu secara mandiri memecahkannya. Guru yang menciptakan, mengelola serta membuat situasi pembejaran menjadi kondusif sehingga anak betah untuk menimba ilmu dan bermanfaat bagi peserta didik. Tugas Guru yaitu mendidik, membimbing pesrta didik dari yang tidak tahu menjadi tahu, dari yang bodo menjadi pinter. Hal tersebut berkaitan antara peserta didik yang satu dengan yang berlainan. Akibat dari kurangnya menguasai manajemen kelas maka akan berakibat pada tidak kondusifnya proses kegiatan pembelajaran.

Peluang untuk memperbaiki pembelajaran menjadi baik masih terbuka lebar, Sehingga dapat memperbaiki pegelolaan kelas. Manajemen yang bagus, dapat menciptakan suasana pembelajaran menjadi lebih kondusif. . Mananjemen kelas yang bagus dapat dipertahankan, hal ini dikarenakan pada kondisi tertentu ada masalahdiinginkan 
datang mendadak dan diluar keterbatasan guru. Guru menyajikan rancangan pembelajaran yang disusun secara periodic, sehingga siswa tinggal memperhatikan serta memahami dengan baik. Siswa juga diharapkan mampu untuk menguasai pembelajaran tersebut. Selain itu guru juga harus menyampaikan suatu metode pembelajarn yang sesuia dengan tingkat pendidikan peserta didik, dalam hal ini khususnya kelas I dengan menggunakan model ekspositori yang bertujuan untuk meningkatkan prestasi belajar. Metode pengajaran merupakan suatu komponen didalam kurikulum lingkungan Bersih, Sehat dan Asri. Di dalam proses kegiatan belajar mengajar guru harus cerdas dalam memilih metode yang tepat yang disesuaikan dengan kebutuhan siswa dalam kondisi dan suasana belajar siswa. Selain peranan guru dalam menyajikan pembelajaran, siswa juga memiliki arti yang akurat.

Arti siswa dalam pembelajaran:

Menemukan infomasi yang faktual, (2) Memakai medi pembeljaran yang tepat (3) mampu menyelesaikan pekerjan dengan benar. Menurut Koontz \& Plank dalamkeberhasilan metode ekspositori sangat tergantun pada guru. Guru mampu menyampaikanrancangan pembelajaran kepada siswa dengan benar. Guru mampu berpikir cerdas untuk membawa ke anak didiknya menjadi lebih maju dan bisa mencapai kesuksesan. Dengan keberhasilan guru dlam menyajikan ideide yang jenius maka akan berdampak pada anak didiknya, sehingga guru menjadi suri teladan bagi anak didiknya terutam bagi siswa SD Kelas I SD Negeri 4 Bareng Lor

\section{PEMBAHASAN}

\section{Efectivitas}

"Efektivitas merupakan ukuran yang memberikan gambaran seberapa jauh target yang dapat dicapai”.

Efektivitas itu dimaksudkan pada pencapaian sasaran yang jelas dan optimal. Terkandung maksud bahwa peningkatan target yang berkaitan dengan mutu, pengguna . Pemberian pelajaran yang sederhana adalah kegiatan belajar mengajar yang mampu meyajikan informasi baru terhadap peserta didik. Untuk memperoleh efektivitas dan efisiensi mengajar diperlukan kemampuan guru dalam mengembangkan berbagai komponen yang ada dalam pembelajaran.

Kemampuan guru dalam menyampaikan pembelajaran dapat ditunjukkan dengan seberapa banyak pesrta didik memperoleh informasi yang up to date. Dengan begitu maka dapat dijadikan alasan bagi guru dalam hal kesuksesan dalam memberikan pelajaran di kelas.. Peserta didik tertarik untuk memahami suatu pelajaran itu tergantung dari isi pelajaran nya dulu, selain itu juga siswa tertarik pada guru yang mengajarnya, seperti dengan cara guru membuat kegiatan pelajaran, guru $\mathrm{m}$ mendidik memakai metode yang tepat, bagaimana guru memakai video atau audio visual, bagaimana guru bersosialita dengan kelompok lain. Untuk tercapainya pembelajaran yang efektif maka pendidik wajib mempunyai ikatan yang luas.seterusnya guru juga harus memberikan bekal dengan workshop

\section{Belajar}

Jadi belajar merupakan kegiatan yang dilakukan hampir setiap orang. Pengetahuan, keterampilan, kebiasaan dan tingkah laku yang pada dasarnya 
dibentuk dan ditempuh melaui proses, seseorang dikatakan belajar bila dalam individu orang tersebut mengalami perubaha itu baik watakkeseharian maupun perbuatan tesebut dapat mengalami peningkatan dalam kegiatan pembelajar yang dilakukan di sekolah.

\section{Metode Ekspositori}

Metode ekspositori hampir sama dengan metode ceramah informasi terpusatnya adalah kepada guru, tetapi dalam metode ini peran guru berkurang dan menuntut siswa agar ebih aktif mengerjakan soal yang diberikan dan membuat pertanyaan dan disampaikan kepada guru dan kemudian jika perlu soal yang menjadi pertanyaan itu ditulis dipapan tulis sehingga teman-teman yang lain akan dapat mengetahui jawaban atas soal yang dipertanyakan tersebut, metode belajar Lingkunga Bersih,Sehat, dan Asri seperti menurut peneliti adalah yang sangat cocok untuk diterapkan.

\section{d. Prinsip-prinsip pengajaran ekspositoris}

1. Hubungan yang berkesinambungan dengan pengetahuan awal sampai akhit proses pembelajaran.

2. Mengajar dengan lingkungan yang kondusif dan pelajarn yang saling keterkaitan yang tepat diantara berbagai isu.

\section{Signal}

Strategi ekspositori diantaranya : Korelasi dan Mengaplikasikan

\section{d. Prestasi Belajar}

"Prestasi" adalah seberapa besar jumlah yang didapat atau diperoleh baik secara pribadi maupun kelompok.. Prestasi gak dapat diperoleh apabila dalam waktu tertentu tidak mengerjakan suatu kegiatan tertentu..Secara realita prestasi didapatkan tidak semudah membalikkan telatak tangan, tetapi diraih dengan suatu pengorbanan walaupun aral melintang tetap harus diperjuangkan demi terciptana sutu tujuan yang jelas. Maka wajar jika prestasi itu pencapaiannya harus dengan giat bekeja. Meski pencapaian prestasi itu penuh dengan rintangan dan tantangan yang harus dihadapi oleh seseorang, tetapi seseorang tidak akan putus asa untuk memperolehnya.. Masih ada cara lain yang dapat dipakai untuk bisa dijadikan sebagai penghubung untuk mendapakan prestasi.

\section{METODE PENELITIAN}

\section{Jenis Penelitian}

Penelitian ini memakai pendekatan kwantitatif. Pendekatan kwantitatif menekankan variabel-variabel yang mendukung obyek penelitian. variabelvariabel tersebut harus dimaknai dalam bentuk operasional.

\section{Waktu Penelitian}

Penelitian ini akan dilakukan pada semester ganjil tahun akademik 2017/2018 pada bulan Desember 2017 s/d Februari 2018. Pelaksanaan penelitian sesuai dengan jadwal pelajaran semester 3 pada SD Negeri 4 Barenglor.

\section{Deskripsi Tempat Penelitian}

Penelitian ini akan dilaksanakan dikelas I SD Negeri 4 Barenglor.

\section{Subjek Penelitian dan}

\section{Karakteristiknya}

Subjek penelitian ini adalah semua siswa kelas I A dan I B SD Negeri 4 Barenglor sebanyak 48 anak. Karakteristik siswa kelas I yang terbiasa dengan pembelajaran yang bersifat teacher centered mengakibatkan prestasi belajar masih rendah.

\section{Teknik dan Instrumen \\ Pengumpulan Data}

\section{Pengamatan}


Sebelum terjun untuk mengadakan pengamatan yang terkandung maksud untuk mencari sumber infomasi maupun data-data yang faktual.

\section{Metode Dokumentasi}

Dokumentasi adalah mencari datdata dengan menulis atau mengamati suatu benda atau suatu laporan yang sudah ada.

\section{Metode Tes}

Metode Test adalah sejumlah daftar kegiatan atau latihan yang harus dipersiapakn terbih dulu.

\section{A. Uji Hipotesis}

1.

\section{Analisis Data}

Untuk mengetahui tingkat efektivitas suatu metode pembelajaran, maka nilai siswa harus mencapai KKM yaitu80. Hal ini dapat dilakukan dengan teknik prosentase dengan rumus:

$$
\mathrm{S}=\frac{\mathrm{R}}{\mathrm{N}} \times 100 \%
$$

Keterangan: $\mathrm{S}=$ jumlah persen yang dicari

$\mathrm{R}=$ jumlah siswa yang mencapai KKM

$\mathrm{N}=$ jumlah keseluruhan siswa

$100=$ bilangan tetap

Dengan kriteria yang terdapat pada tabel :

Tabel

4.1Kriteria

Tingkat

Efektivitas Metode Pembelajaran

\begin{tabular}{|c|c|c}
\hline No & Prosentase Siswa & Predikat \\
\hline 1 & $86 \%-100 \% \geq$ SKM & Sangat Efektif \\
2 & $76 \%-85 \% \geq$ SKM & Efektif \\
3 & $60 \%-75 \% \geq$ SKM & Cukup Efektif \\
4 & $55 \%-59 \% \geq$ SKM & Kurang Efektif \\
5 & $\leq 54 \% \geq$ SKM & Tidak Efektif \\
\hline
\end{tabular}

a. Efektivitas Metode Ekspositori terhadap Prestasi Belajar.

nilai yang mencapai KKM yang telah ditetapkan sebanyak 28 siswa dari 48 siswa yang ada. Untuk mengetahui tingkat efektivitas metode ekspositori terhadap prestasi belajar siswa dilakukan teknik prosentase dengan rumus:

$$
\begin{aligned}
& S=\frac{R}{N} \times 100 \% \\
& =\frac{25}{40} \times 100 \% \\
& =\frac{2500}{40} \% \\
& =62,5 \%
\end{aligned}
$$

Berdasarkan perhitungan tersebut dapat diketahui bahwa siswa yang mendapatkan nilai sesuai KKM $(\geq 75)$ sebanyak 62,5 \%. Daftar pengelompokan kriteria tersebut dapat dilihat dalam tabel di bawah ini:

Tabel 4.2Kriteria Tingkat Efektivitas Metode Pembelajaran

\begin{tabular}{|c|c|c|}
\hline No & Prosentase Siswa & Predikat \\
\hline 1 & $86 \%-100 \% \geq$ SKM & Sangat Efektif \\
2 & $76 \%-85 \% \geq$ SKM & Efektif \\
3 & $60 \%-75 \% \geq$ SKM & Cukup Efektif \\
4 & $55 \%-59 \% \geq$ SKM & Kurang \\
5 & $\leq 54 \% \geq$ SKM & Efektif \\
& & Tidak Efektif \\
\hline
\end{tabular}

Setelah dilihat dalam tabel di atas, 62,5\% terletak pada tingkat $60 \%-75 \% \geq \mathrm{KKM}$ yaitu pada predikat cukup efektif. Efektivitasnilai yang mencapai KKM yang telah ditetapkan sebanyak 35 siswa dari 41 siswa yang ada. Untuk mengetahui tingkat efektivitas dilakukan teknik prosentase

$$
\mathrm{S}=\frac{\mathrm{R}}{\mathrm{N}} \times 100 \%
$$

dengan rumus:

$$
\begin{aligned}
& =\frac{38}{41} \times 100 \% \\
& =\frac{3800}{41} \% \\
& =92,68 \%
\end{aligned}
$$


Setelah dilihat dalam tabel di atas, 92,68\% terletak pada tingkat $86 \%-100 \% \geq \mathrm{KKM}$ yaitu pada predikat sangat efektif.

\section{Uji Hipotesis}

Untuk menganalisis data hasil post test yang diberikan kepada kelas tersebut, kontrol dan Eksperimen maka diambil uji signifikansi yaitu:

\section{UJI PRASYARAT NILAI PRETES}

\section{UJI NORMALITAS}

a. $\mathrm{H}_{0} \quad$ Sampel berasal dari populasi yang berdistribusi normal

$\mathrm{H}_{1} \quad=$ Sampel berasal dari populasi yang tidak berdistribusi normal

b. Keputusan uji normalitas adalah: apabila signifikansi $<0,05$ maka $\mathrm{H}_{0}$ ditolak, dan apabila signifikansi $>0,05$ maka $\mathrm{H}_{0}$ diterima.

c. Statistik uji

Uji Normalitas dengan SPSS 20

d. Komputasi

\section{Tests of Normality}

\begin{tabular}{r|l|l|l|l|l|l|l}
\hline & Kelas & \multicolumn{3}{|c|}{ Kolmogorov-Smirnov ${ }^{\mathrm{a}}$} & \multicolumn{3}{|c}{ Shapiro-Wilk } \\
\cline { 3 - 7 } & & Statistic & df & Sig. & Statistic & df & Sig. \\
\hline \multirow{2}{*}{$\begin{array}{l}\text { Kontrol } \\
\text { Pretes }\end{array}$} & 154 & 24 &, 143 &, 929 & 24 &, 094 \\
& $\begin{array}{c}\text { Eksperi } \\
\text { men }\end{array}$ & 156 & 24 &, 136 &, 882 & 24 &, 009 \\
\hline
\end{tabular}

a. Lilliefors Significance Correction

e. Kesimpulan

Berdasarkan uji normalitas dengan jenis uji KolmogorovSmirnovdiperoleh taraf signifikansi sebesar 0,143 untuk nilai pretest kelas kontrol dan 0,136 untuk nilai pretest kelas eksperimen. Dapat disimpulkan bahwa nilai pretestkelas kontrol dan kelas eksperimen lebih besar dari $\alpha=0,05(\operatorname{sig}>0,05)$ maka $\mathrm{H}_{0}$ diterima. Artinya sampel berasal dari populasi yang berdistribusi normal.

\section{UJI HOMOGENITAS}

a. $\mathrm{H}_{0}=$ Sampel berasal dari variansi yang sama (homogen)

$\mathrm{H}_{1} \quad=$ Sampel berasal dari variansi yang tidak sama (homogen)

b. Keputusan uji homogenitas diperoleh apabila signifikansi $<0,05$ maka $\mathrm{H}_{0}$ ditolak, dan apabila signifikansi $>0,05$ maka $\mathrm{H}_{0}$ diterima.

c. Statistik uji

d. Komputasi

$$
\text { Uji Homogenitas dengan SPSS } 20
$$

Test of Homogeneity of Variances

\begin{tabular}{r|r|r|r}
\multicolumn{1}{l}{ Pretes } \\
\hline Levene Statistic & df1 & df2 & \multicolumn{2}{|c}{ Sig. } \\
\hline 3,452 & 1 & 46 &, 070 \\
\hline
\end{tabular}

e. Kesimpulan

Uji homogenitas diperoleh taraf signifikansi sebesar 0,070menunjukkan bahwa lebih kecil dari $\alpha=0,05(\operatorname{sig}>0,05)$ maka $\mathrm{H}_{0}$ diterima. Jadi, variansi setiap sampel homogen.

\section{UJI PRASYARAT KELAS UJI NORMALITAS}

a. $\mathrm{H}_{0} \quad=$ Sampel berasal dari populasi yang berdistribusi normal

$\mathrm{H}_{1} \quad=$ Sampel berasal dari populasi yang tidak berdistribusi normal

b. Keputusan uji normalitas adalah: apabila signifikansi $<0,05$ maka $_{0}$ ditolak, dan

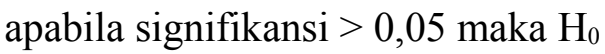
diterima.

c. Statistik uji

Uji Normalitas dengan SPSS 20

d. Komputasi 
Tests of Normality

\begin{tabular}{l|r|r|r|r|r|r}
\hline \multirow{2}{*}{ Kelas } & \multicolumn{3}{|c|}{ Kolmogorov-Smirnov } & \multicolumn{3}{|c}{ Shapiro-Wilk } \\
\cline { 2 - 7 } & Statistic & \multicolumn{1}{c}{ df } & Sig. & Statistic & \multicolumn{1}{c}{ df } & \multicolumn{1}{c}{ Sig. } \\
\hline PKontrol &, 147 & 24 &, 197 &, 938 & 24 &, 149 \\
$\mathrm{o}$ & & & & & & \\
S Eksperi $_{\text {t }}, 161$ & 24 &, 110 &, 935 & 24 &, 126 \\
$\mathrm{e}^{\text {men }}$ & & & & & & \\
$\mathrm{s}$ & & & & & & \\
\hline
\end{tabular}

a. Lilliefors Significance Correction

e. Kesimpulan

Berdasarkan uji normalitas dengan jenis uji Kolmogorov-

Smirnovdiperoleh taraf signifikansi sebesar 0,197 untuk nilai posttest kelas kontrol dan 0,110 untuk nilai posttest kelas eksperimen. Dapat disimpulkan bahwa nilai posttest kelas kontrol dan kelas eksperimen lebih besar dari $\alpha=0,05$ (sig $>0,05)$ maka $\mathrm{H}_{0}$ diterima. Artinya sampel berasal dari populasi yang berdistribusi normal,

\section{UJI HOMOGENITAS}

a. $\mathrm{H}_{0} \quad$ Sampel berasal dari variansi yang sama (homogen)

$\mathrm{H}_{1} \quad=$ Sampel berasal dari variansi yang tidak sama (homogen)

b. Keputusan uji homogenitas diperoleh apabila signifikansi $<0,05$ maka $\mathrm{H}_{0}$ ditolak, dan apabila signifikansi $>0,05$ maka $\mathrm{H}_{0}$ diterima.

c. Statistik uji

Uji Homogenitas dengan SPSS 20

d. Komputasi

Test of Homogeneity of Variances

Postes

\begin{tabular}{r|r|r|l}
\hline $\begin{array}{c}\text { Levene } \\
\text { Statistic }\end{array}$ & df1 & df2 & Sig. \\
\hline, 822 & 1 & 46 &, 369 \\
\hline
\end{tabular}

e. Kesimpulan

Uji homogenitas diperoleh taraf $\mathrm{s}$ 0,369 menunjukkan bahwa lebih
( $\operatorname{sig}>0,05)$ maka $\mathrm{H}_{0}$ diterima. Jadi, variansi setiap sampel homogen.

\section{UJI EFEKTIFITAS}

Model Pembelajaran ekspositori

1. Hipotesis

$\mathrm{H}_{0}=$ Tidak terdapat perbedaan yang berarti antara hasil belajar yang menggunakan pembelajaran tematik integratif berbasis sosiokultural dengan pembelajaran standar di sekolah.

$\mathrm{H}_{1}=$ Terdapat perbedaan yang berarti antarahasil belajar yang menggunakan pembelajaran tematik integratif berbasis sosiokultural dengan pembelajaran standar di sekolah.

2. Kriteria pengambilan keputusan uji:

a. Apabila nilai signifikansi $<0,05$ maka $\mathrm{H}_{0}$ ditolak.

b. Apabila nilai signifikansi $>0,05$ maka $\mathrm{H}_{0}$ diterima.

3. Statistik Uji

Uji Homogenitas dengan SPSS 20

\section{Komputasi}

5. Kesimpulan

Hasil :

Variance kedua kelompok sama (P value $0,369>0,05(\alpha)$ ), maka analisis $T$ test menggunakan asumsi Equal variance yaitu dengan melihat $t$ hitung atau $P$ value.

Hasil thitung menunjukkan -4,643 dengan $\mathrm{P}$ value $0,000<0,05(\alpha)$. 
Dapat disimpulkan $\mathrm{H}_{0}$ ditolak dan $\mathrm{H}_{1}$ diterima, artinya terdapat perbedaan yang berarti antara prestasi belajar yang menggunakan model pembelajaran ekspositori dengan pembelajaran standar di sekolah.

Berdasarkan analisis data diperoleh perbedaan yang berarti antara prestasi belajar yang menggunakan model pembelajaran ekspositori dengan pembelajaran standar di sekolah. Hal ini dapat dilihat dari uji independensi yang menunjukkan hasil signifikansi kurang dari $0,05(\operatorname{sig}<0,05)$.

Kemudian dilihat dari reratanya, pembelajaran dengan mengacu pembelajaran tematik integratif berbasis sosiokultural (yaitu 46) menghasilkan rerata yang lebih tinggi dibandingkan dengan pembelajaran standar di sekolah (yaitu 44).

Jadi kesimpulannya adalah model pembelajaran ekspositori adalah pembelajaran yang efektif.

\section{Gain dan $N$-gain (lihat excel)}

Gain dan N-gainbertujuan untuk mengetahui peningkatan pretes dan postes kelas eksperimen. Hasil gain dan N-gain posttest

belajarsiswa kelas eksperimen. Tabel. 4.3 Hasil Gain dan N-gainPrestasi Belajar eksperimen Kelas

Jeni $\mathrm{N}$ Minimum Maksimu Rata- $^{\text {Std. }}$

$\mathrm{s} \quad \mathrm{m}$ rata Deviasi

yaitu 2 angka, sedangkan nilai gain maksimum sebesar 24 artinya siswa mengalami peningkatan tertinggi adalah 24 angka. N-gain mendapatkan hasil minimum sebesar 0,09 (kriteriarendah), dan N-gain mendapatkan hasil maksimum sebesar 0,69 (kriteria sedang), serta rata-rata sebesar 0,35 (kriteria sedang).

Berikut tabel 4.4 ketetapan kriteria nilai normalisasi gain score.

Tabel 4.4 Kriteria Normalisasi Gain

Score

\begin{tabular}{ll}
\hline Nilai $<\mathbf{g}>$ & Kriteria \\
\hline$<g>\geq 0,7$ & Tinggi \\
$0,7><g>\geq 0,3$ & Sedang \\
$<g><0,3$ & Rendah \\
(Sumber: Hake, 1998)
\end{tabular}

\section{Kriteria $\mathrm{N}$-gainprestasi belajar siswa kelas eksperimen dapat dilihatpada} Tabel.

DariTabel 4. 4cdapat diketahui bahwa sebaran skor $\mathrm{N}$-gain tersebar dari kriteria rendah dan kriteria sedang. Artinya terdapat peningkatan prestasi belajar setelah $\mathrm{N}$-gain menggunakan

Frekuensi Persentase perangkat

(\%)

\begin{tabular}{ccll}
$<g>\geq 0,7$ & Tinggi & 0 & 0 \\
$\begin{array}{c}0,7><g>\geq 0, \\
3\end{array}$ & Sedang & 14 & 58,33 \\
$<g><0,3$ & Rendah & 10 & 41,67 \\
\hline \multicolumn{2}{c}{ Jumlah } & 24 & 100
\end{tabular}
pembelajaran yang dikembangkan.

Tabel. Hasil Gain dan N-gainPrestasi Belajar Kelas kontrol

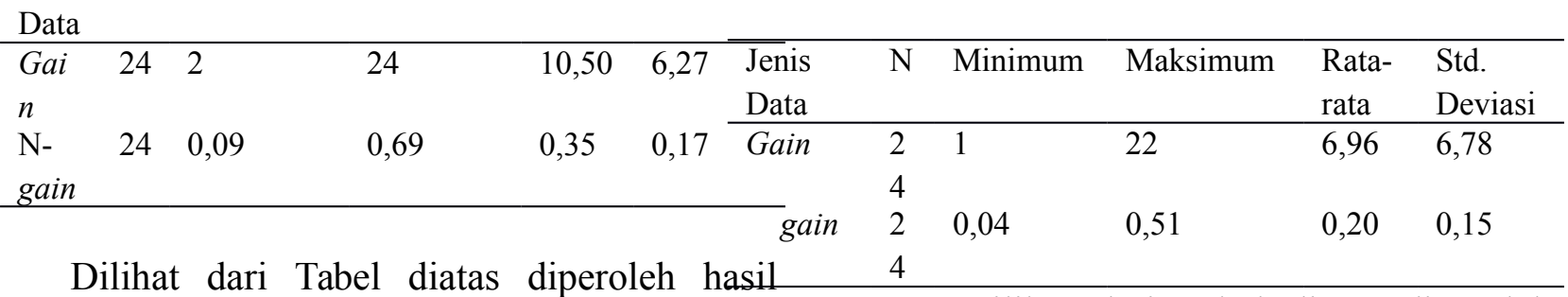
yaitu nilai gain minimum sebesar 2 artinya siswa mengalami penurunan nilai terendah
Dilihat dari Tabel diatas diperoleh hasil yaitu nilai gain minimum sebesar 1 
artinya siswa mengalami peningkatan nilai terendah yaitu langka, sedangkan nilai gain maksimum sebesar 22 artinya siswa mengalami peningkatan tertinggi adalah 22 angka. N-gain mendapatkan hasil minimum sebesar 0,04 (kriteriarendah), dan $\mathrm{N}$-gain mendapatkan hasil maksimum sebesar 0,51 (kriteria sedang), serta rata-rata sebesar 0,20 (kriteriarendah).

Berikut tabel ketetapan kriteria nilai normalisasi gain score.

Tabel 3.3. Kriteria Normalisasi Gain Score

\begin{tabular}{ll}
\hline Nilai $<$ g $>$ & Kriteria \\
\hline$<g>\geq 0,7$ & Tinggi \\
$0,7><g>\geq 0,3$ & Sedang \\
$<g><0,3$ & Rendah
\end{tabular}

(Sumber: Hake, 1998)

\section{Kriteria N-gainprestasi belajar siswa kelas eksperimen dapat dilihatpada} Tabel.

\begin{tabular}{|c|c|c|}
\hline Nilai & Kriteria & \\
\hline$<g>\geq 0,7$ & Tinggi & 0 \\
\hline $0,7><g>\geq 0,3$ & Sedang & 7 \\
\hline$<g><0,3$ & Rendah & 17 \\
\hline \multicolumn{2}{|c|}{ Jumlah } & 24 \\
\hline
\end{tabular}

DariTabel dapat diketahui bahwa sebaran skor N-gain tersebar dari kriteria rendah dan kriteria sedang. Artinya terdapat peningkatan hasil belajar setelah menggunakan perangkat pembelajaran yang dikembangkan.

Disimpulkan pula adanya peningkatan pretes dan postes kelas eksperimen lebih besar daripada kelas kontrol.

\section{c. PENUTUP}

1. Kesimpulan

Berdasarkan hasil penelitian maka pembelajaran ekspositori terbukti dapat meningkatkan prestasi belajar pada tema 6 Lingkungan Besih, Sehat dan Asri subtema Lingkungan Rumahku pada siswa kelas I SD Negeri 4 bareng Lor, Kecamatan Klaten utara, Klaten. Hal ini terlihat dari berbagai uji coba yang dilakukan oleh peneliti. :

Variance kedua kelompok sama ( $\mathrm{P}$ value $0,369>0,05(\alpha)$ ), maka analisis $\mathrm{T}$ test menggunakan asumsi Equal variance yaitu dengan melihat $t$ hitung atau $P$ value. Hasil $\mathrm{t}$ hitung menunjukkan $-4,643$ dengan $\mathrm{P}$ value $0,000<0,05(\alpha)$.

Dapat disimpulkan $\mathrm{H}_{0}$ ditolak dan $\mathrm{H}_{1}$ diterima, artinya terdapat perbedaan yang berarti antara prestasi belajar yang menggunakan model pembelajaran ekspositori dengan pembelajaran standar di sekolah.

$\begin{array}{lrr}\begin{array}{l}\text { Kemudian dilihat dari } \\ \text { pembelajaran }\end{array} & \begin{array}{r}\text { reratanya, } \\ \text { dengan }\end{array} & \begin{array}{r}\text { mengacu } \\ \text { (yaitu } 46)\end{array} \\ \text { pembelajaran } & \text { ekspositori } & \text { (yaitu } \\ \text { menghasilkan } & \text { rerata yang lebih tinggi } \\ \text { dibandingkan } & \text { dengan } & \text { metode } \\ \text { pembelajaran lain (yaitu } & 44 \text { ). Jadi } \\ \text { kesimpulannya adalah } & \text { model } \\ \text { pembelajaran } & \text { ekspositori } & \text { adalah } \\ \text { pembelajaran yang efektif. }\end{array}$

2. Saran

Setelah dikemukakan kesimpulan di atas, maka perlu penulis kemukakan saran-saran sebagai berikut:

1 Bagi Kepala Sekolah

Sebagai masukan untuk menentukan haluan kebijakan dalam membantu meningkatkan prestasi belajar matematika siswa.

2 Bagi Guru

Hasil penelitian ini diharapkan dapat dijadikan bahan masukan untuk 
memperbaiki kegiatan pembelajaran, khususnya tentang penggunaan metode pembelajaran ekspositori dan model pembelajaran individual berbantuan modul.

3 Bagi Siswa

Hasil penelitian ini diharapkan akan dapat meningkatkan prestasi belajar matematika siswa.

4 Bagi Peneliti

Hasil penelitian ini dapat dijadikan pijakan untuk mengembangkan penelitian lainnya khususnya di bidang pendidikan.

\section{DAFTAR PUSTAKA}

Arifin, Zainal. (2011). Evaluasi Pembelajaran. Bandung: PT Remaja Rosdakarya.

Arikunto, Suharsani. (2006). Prosedur Penelitian Suatu Pendekatan Praktik. Jakarta: Rineka Cipta.

Djamarah, Syaiful Bahri dan Aswan Zain. (2010). Strategi Belajar Mengajar. Jakarta: Rineka Cipta.

Djamarah, Syaiful Bahri. Prestasi Beajar dan Kompetensi Guru. Surabaya: Usaha Nasional.

Hajar, Ibnu. (1999). Dasar-Dasar Metodologi Penelitian Kuantitatif Dalam Pendidikan. Jakarta: Raja Grafindo Persada..

Hamalik, Oemar. (2009). Proses Belajar Mengajar, Jakarta: PT Bumi Aksara,
Hudojo, Herman. (1988). Mengajar Belajar Matematika. Jakarta: Departemen Pendidikan dan Kebudayaan Direktorat Jenderal Pendidikan Tinggi

Hasbullah. (2003). Dasar- dasar Ilmu Pendidikan. Jakarta: PT Raja Grafindi Persada

Mulyasa, E. (2006). Kurikulum yang Disempurnakan, Bandung: PT Remaja Rosdakarya,

-------. (2005). Manajemen Berbasis

Sekolah, Bandung: PT Remaja Rosdakarya Offset.

KurikulumBerbasisKompetensi, Bandung: PT Remaja Rosdakarya, Sudjana, Nana dan Ahmad Rivai. (2007). Teknologi Pengajaran, Bandung: Sinar Baru Algensindo

Sudjana, Nana dan Ibrahim. (2007). Penelitian dan Penilaian Pendidikan, Bandung: Sinar Baru Algensindo

Sudjana, Nana. (1989). Dasar-dasar Belajar Mengajar, Bandung: Sinar Baru Sudjana. (2005). Metoda Statistika, Bandung: Tarsito

Sugiono. (2018). Metode Penelitian Kuantitatif, Kualitatif, dan R7D. Bandung: Alfabeta 